\title{
MICROBIOLOGICAL QUALITY OF WELL WATER FROM KOPRIVNICA-KRIŽEVCI COUNTY IN 2018
}

\author{
Sanja Furmeg ${ }^{1 *}$, Lana Feher Turković ${ }^{2}$, Ana Mojsović Ć uić ${ }^{2}$, Vesna Jaki Tkalec ${ }^{1}$, Maja Kiš ${ }^{1}$ \\ ${ }^{I}$ Croatian Veterinary Institute, Veterinary Department Križevci, Ivana Zakmardija Dijankovečkog 10, 48260 \\ Križevci, Croatia \\ ${ }^{2}$ University of Applied Health Sciences, Mlinarska cesta 38, 10000 Zagreb, Croatia \\ *E-mail of corresponding author: sanja.furmeg@gmail.com
}

\begin{abstract}
In this study, microbiological quality of drinking water deriving from the private wells from Koprivnica-Križevci County was investigated. A total of 287 samples from different locations were collected during 2018 and analysed for the following microbiological parameters: total coliforms, Escherichia coli, Enterococcus spp., Clostridium perfringens, Pseudomonas aeruginosa, and the number of aerobic heterotrophic bacteria at $36{ }^{\circ} \mathrm{C}$ and $22{ }^{\circ} \mathrm{C}$. The results showed that 24 $\%$ of the analysed water samples were of unsatisfactory microbiological quality, with high incidence of faecal contamination. Well water is still the main source of drinking water for many residents of this County, especially in its rural parts, so continuous monitoring and disinfection of drinking water deriving from private wells is of exceptional importance for the public health.
\end{abstract}

Keywords: drinking water, water microbiology, private wells, health safety.

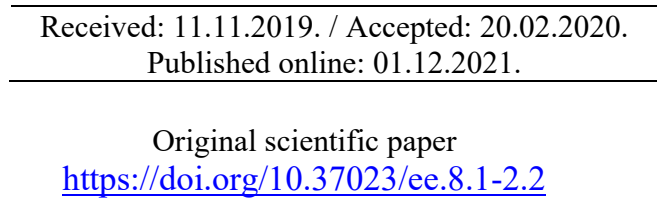

\section{INTRODUCTION}

According to data of Croatian Institute of Public Health (2018), more than $87 \%$ of Croatian population uses public water supply system and drinks tap water, which is regularly controlled and conforms to health safety standards. It means that more than $13 \%$ households in Croatia rely on private wells as their only source of drinking water. Health safety of well water intended for human consumption depends upon several factors. These primarily include quality and purity of raw water, technology of purification and application of disinfecting procedures. Sanitary-technical and hygienic conditions of the water supply objects also have great importance in maintaining drinking water quality. Monitoring of drinking water deriving from public water supply systems is carried out on a national level, while monitoring of well water or local water supply systems is performed only upon an owner's personal request. Drinking water has to possess good sensory features (no colour, taste and odour), without the presence of substances in concentrations which could detrimentally influence the human organism as well as without agents causing diseases (pathogens) which could be transferred through drinking water (Vukić Lušić et al. 2017). In order to prevent hydric infections, it is of outmost importance to have a constant control of drinking water safety, which is also prescribed by the Law on the Water Intended for Human Consumption (Official Gazette 56/13, 64/15, 104/17, 115/18).

Routine microbiological analysis of drinking water plays an essential role in measures to protect public health. In general terms, the greatest microbial risks are associated with consumption of water that is contaminated with human or animal faeces. Wastewater discharges and inadequate drainage from nearby facilities (septic tanks, stables) are the major source of faecal microorganisms, including pathogens (Cabral 2010). Water-related infections are transferred and spread through the water on the limited area within a relatively short period of time, and may occur as endemic, pandemic or individually. It is not only bacteria, viruses and parasites that may be transferred by water, but also their toxins which may be present in the water even when the microorganisms are no longer there (Marjanović \& Tofant 2008).

Health safety control of drinking water in Croatia is conducted pursuant to the Croatian water quality regulations (Official Gazette 125/17). In Koprivnica-Križevci County there is a developed public water supply system, with its tendency for expansion. However, private wells and local water supply systems are still the only source of drinking water for the residents in the rural parts of the County. Private wells are also used as source of drinking water for farm animals (Denžić Lugomer et al. 2019).

Since microbiological contamination of drinking water may present a great risk for human health, but also for the health of animals, the goal of this research was to establish the microbiological status of water from the private wells from Koprivnica-Križevci County. 


\section{MATERIALS AND METHODS}

Well water samples from different locations in Koprivnica-Križevci County were submitted to the Laboratory of Food and Feed Microbiology, Veterinary Department Križevci for microbiological analysis. Most of the samples were collected by qualified laboratory employees, in clean, sterile glass bottles and transported in cooling boxes to the laboratory within six hours from the sampling, guided by the rules of good laboratory practice. Immediately after arriving to the laboratory, the samples were subjected to microbiological analysis. Some of the samples were delivered by owners, who were prior given a sterile bottle for sampling and detail instructions about the proper sampling methods for well water samples. A total of 287 well water samples were collected during 2018. Conducted microbiological analysis included following parameters: total coliforms, Escherichia coli, Enterococcus spp., Clostridium perfringens, Pseudomonas aeruginosa and the number of aerobic heterotrophs at $36^{\circ} \mathrm{C}$ and $22{ }^{\circ} \mathrm{C}$.

For confirming and determining the total number of coliform bacteria and E. coli in water samples, the membrane filtration method was used, according to the standard procedure EN ISO 9308-1:2014/A1:2017. In case of $E$. coli and total coliforms, the solid selective agar CCA (Chromocult ${ }^{\circledR}$ Coliform Agar, Merck, Germany) was used and incubated at $36 \pm 2{ }^{\circ} \mathrm{C}$ for $21 \pm 3$ hours. The typical colonies of $E$. coli are dark blue to violet, indole positive and oxidase negative. The total coliform bacteria on CCA range from pink to red colonies and were confirmed as oxidase negative and no indole production (Figure 1A).

For confirming and determining the number of Enterococcus spp. by membrane filtration method, prescribed by the standard procedure EN ISO 7899 -2:2000, Slanetz and Bartley agar (Merck, Germany) was used and incubation temperature at $37 \pm 0.5^{\circ} \mathrm{C}$ for $44 \pm 4$ hours (Figure 1B).

For enumeration of vegetative cells and spores of $C$. perfringens, the method of membrane filtration was used, according to the standard procedure EN ISO 14189:2016. The volume of $100 \mathrm{ml}$ of water sample was filtrated through the membrane filter (pore size $0.20 \mu \mathrm{m}$ ). TSC agar (Tryptone Sulfite Cycloserine Agar, Biokar, France) was used and incubated in anaerobic conditions at $44{ }^{\circ} \mathrm{C}$ for 24 hours.

Detection of $P$. aeruginos $a$ was conducted pursuant to the standard procedure EN ISO 16266:2008, using the membrane filtration method. Pseudomonas Agar (Merck, Germany) was incubated at $36 \pm 2{ }^{\circ} \mathrm{C}$ during $44 \pm 4$ hours. This is a selective medium containing cetrimide. Typical colonies produce pigment pyocyanin giving the blue-green colour. Typical $P$. aeruginosa colonies are oxidase positive, fluorescent under the UV light (360 \pm 20 $\mathrm{nm}$ ) and they can produce ammonia from the acetamide (Figure 1C).

For determining the number of aerobic heterotrophic bacterial colonies (heterotrophic plate count), a procedure was used according to the norm EN ISO 6222:2000. The number of microorganism colonies was established in 1 $\mathrm{ml}$ of water sample, by using pouring plate method with Yeast Extract Agar (Merck, Germany). The plates were incubated at $22 \pm 1{ }^{\circ} \mathrm{C}$ for 68 hours and at $36^{\circ} \mathrm{C}$ during $44 \pm 4$ hours (Figure 1D).

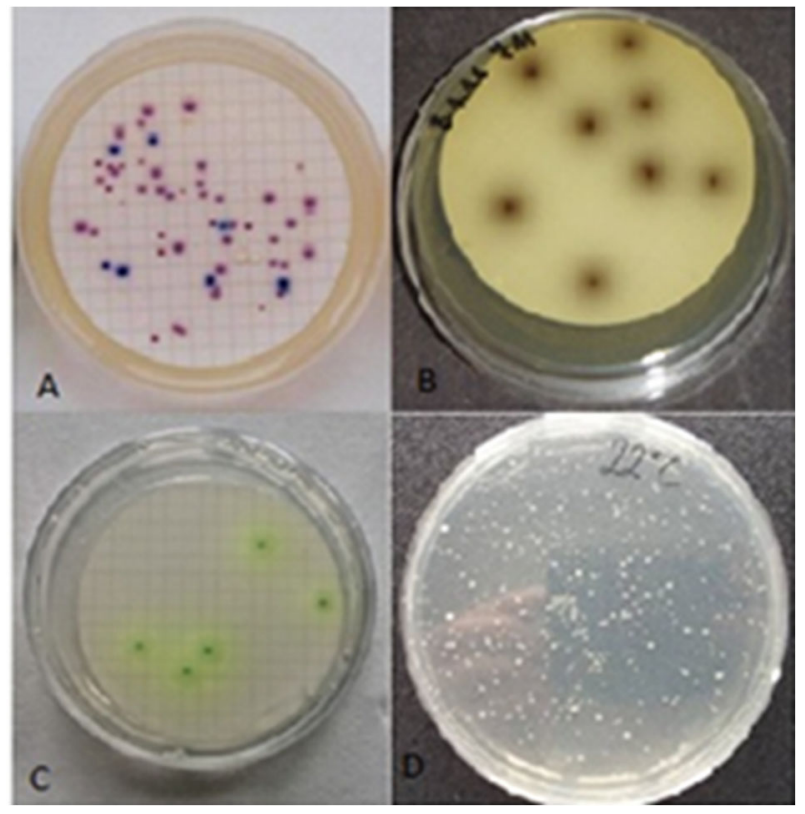

Figure 1. Representative groups of bacteria isolated from well water: A) Escherichia coli and coliform bacteria on the CCA agar; B) Enterococcus spp. on the BAA agar; C) Pseudomonas aeruginosa on a selective Pseudomonas agar; D) Number of colonies of aerobic heterotrophic bacteria on the YEA agar (source: Veterinary Department Križevci) 


\section{RESULTS AND DISCUSSION}

Water for human consumption must meet the standards defined by the Ordinance on conformity parameters, analytical methods, monitoring and drinking water safety plans, and keeping register of legal entities which provide public water supply (Official Gazette 125/17). Maximum Permissible Concentrations (MPC) set by this Ordinance for the number of colonies at $22{ }^{\circ} \mathrm{C}$ are up to $100 \mathrm{CFU} / \mathrm{ml}$; for the number of colonies at $36^{\circ} \mathrm{C}$ up to $20 \mathrm{CFU} / \mathrm{ml}$, whereas for E. coli, total coliforms, Enterococcus spp., C. perfringens and P. aeruginosa, defined MPC are 0 $\mathrm{CFU} / 100 \mathrm{ml}$.

Considering that, among 287 analysed well water samples, $76.0 \%$ (218 samples) were compliant to Ordinance (Official Gazette 125/17). The percentages of unsatisfactory samples per individually analysed microbiological parameter, are shown in Table 1. The microbiological quality of well waters significantly differs from one well to another according to indicators of faecal contamination. Results of total coliform bacteria determination showed that the number of colonies ranges from $0 \mathrm{CFU} / 100 \mathrm{~mL}$ up to $206 \mathrm{CFU} / 100 \mathrm{ml}$. The results of this study showed that 67 samples were unsatisfactory due to determined presence of coliforms. Presence of $E$. coli bacteria, as well as the presence of Enterococcus spp. in water is the most common indicator of faecal pollution. E. coli is a part of the normal intestinal microflora of humans and animals, therefore is widely distributed in the environment, mainly by different human activities. Water contaminated with E. coli and intestinal enterococci presents a high potential risk for the human health. Figure 2 shows the concentration of E. coli in 287 analysed well water samples. The number of colonies varies from $1 \mathrm{CFU} / 100 \mathrm{ml}$ up to $150 \mathrm{CFU} / 100 \mathrm{ml}$. Results of Enterococcus spp. determination showed that the number of colonies ranges from $0 / 100 \mathrm{ml}$ to $127 / 100 \mathrm{ml}$ (Figure 3). Results of this study showed that the $E$. coli is present in 59 samples $(20.6 \%)$, which indicate poor microbiological quality of the examined water samples. The number of Enterococcus spp. colonies in the analysed samples varies from 2/100 $\mathrm{ml}$ up to $127 / 100 \mathrm{ml}$. According to the Croatian water quality regulations (Official Gazette 125/17), 56 samples (19.5\%) were unsatisfactory due to this parameter (Figure 4).

Table 1. Unsatisfactory well water samples pursuant to the Maximum Permissible Concentrations set out by the Croatian water quality regulations per individually analysed microbiological parameter

\begin{tabular}{|c|c|c|}
\hline ANALYSED PARAMETER & $\begin{array}{c}\text { NUMBER OF UNSATISFACTORY } \\
\text { SAMPLES } \\
\text { (Out of total 287 water samples) }\end{array}$ & $\%$ \\
\hline Total coliforms & 67 & 23.34 \\
\hline Escherichia coli & 59 & 20.56 \\
\hline Enterococcus spp. & 56 & 19.51 \\
\hline Clostridium perfringens & 1 & 0.35 \\
\hline Pseudomonas aeruginosa & 11 & 3.83 \\
\hline $\begin{array}{c}\text { Heterotrophic plate count at } \\
22^{\circ} \mathrm{C}\end{array}$ & 64 & 22.30 \\
\hline $\begin{array}{c}\text { Heterotrophic plate count at } \\
36^{\circ} \mathrm{C}\end{array}$ & 68 & 23.69 \\
\hline
\end{tabular}

Sulphite-reducing clostridia, namely C. perfringens, are spore-forming Gram-positive, non-motile, anaerobic, sulphite-reducing rods. C. perfringens is present in higher numbers in the faeces of some animals (such as dogs) and less often of many other warm-blooded animals and humans. Because of ability to produce endospores, it is exceptionally resistant to unfavourable conditions in water environments, including UV irradiation, temperature and $\mathrm{pH}$ extremes and disinfection processes, such as chlorination (Cabral 2010). The presence of $C$. perfrigens in water indicates contamination with faeces or wastewaters for a longer period of time (Denžić Lugomer et al. 2017). In this study, the presence of this anaerobic bacterium was established only in one sample, with concentration of $13 \mathrm{CFU} / 100 \mathrm{ml}$.

Presence of opportunistic pathogen $P$. aeruginosa indicate inadequate maintenance of the water supply system and it is very important that drinking water is without it. Bacteria of this genus are capable of growing in environments with small amounts of nutrients. It is highly resilient, changes odour, colour and taste of water and is responsible for the occurrence of the biofilm in water distribution system. Despite of the widespread distribution of $P$. aeruginosa in the different environments such as soil, water and sewage, water contamination with this bacterium is considered to occur in low proportion, regards to other water contaminants (Vukić Lušić et al. 2017). In this study, $P$. aeruginosa was detected in only $3.83 \%$ of the analysed samples (Figure 4D). 
Denžić Lugomer et al. (2019) investigated the water quality on farms in northwest Croatia and determined the presence of $P$. aeruginosa in $5.8 \%$ of analysed samples. All the unsatisfactory samples in that study came from water wells, while all samples from water distribution system were satisfactory. In a study by Vukić Lušić et al. (2017), P. aeruginosa was detected in only $0.3 \%$ analysed samples from water distribution system in PrimorjeGorski kotar County during 2014.-2016.

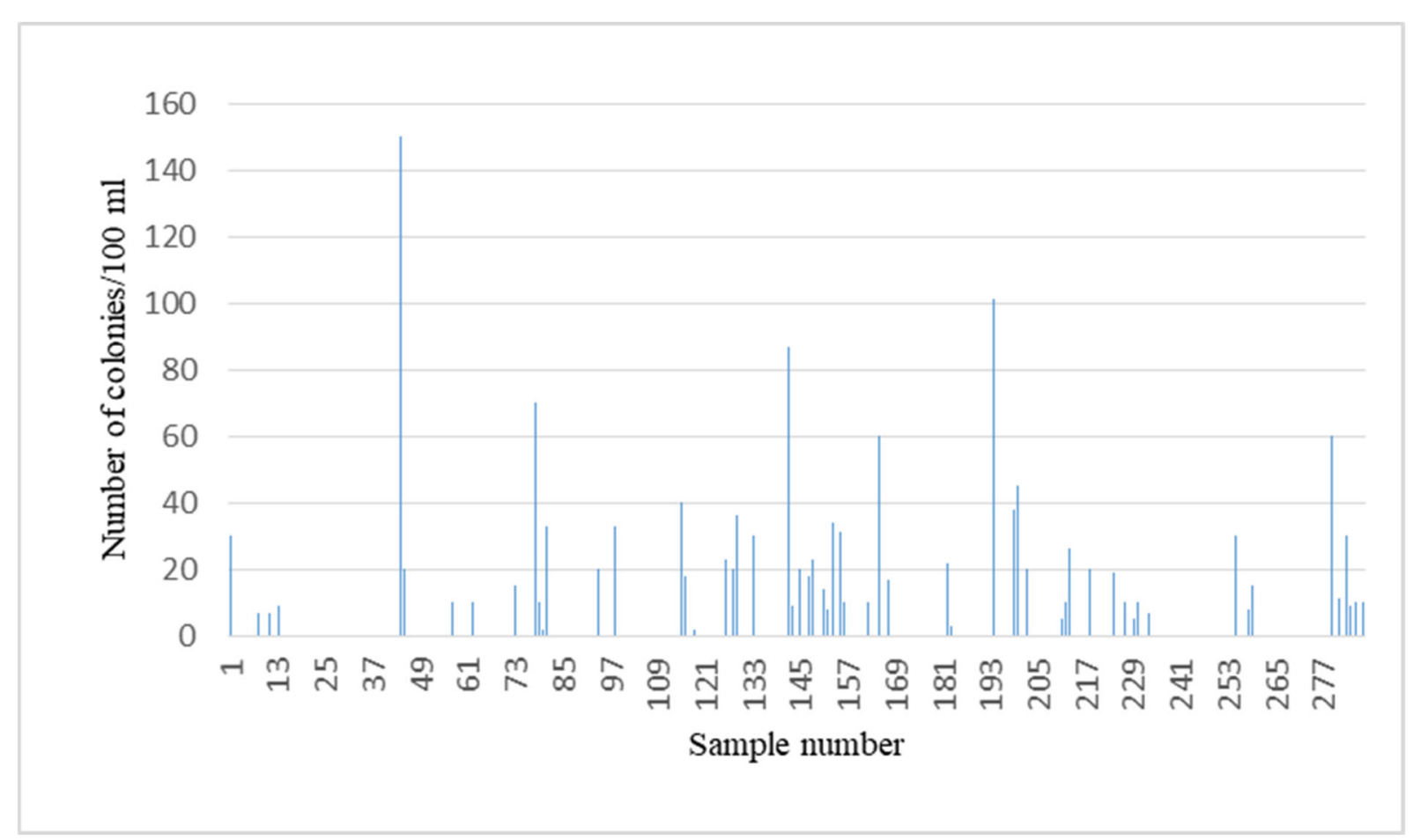

Figure 2. Variation of E. coli $(C F U / 100 \mathrm{ml})$ in analysed well water samples

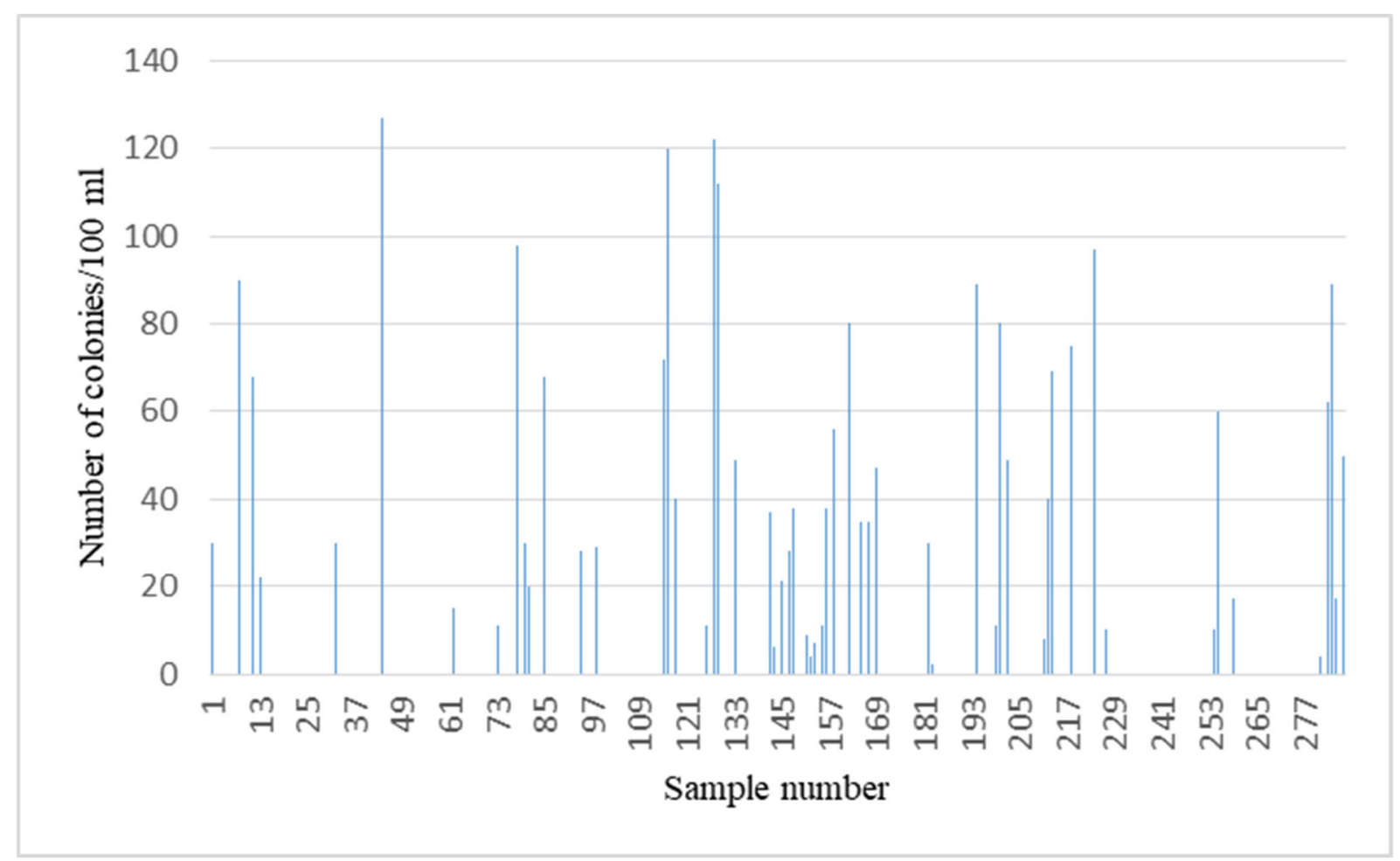

Figure 3. Variations of Enterococcus spp. (CFU/100 ml) in analysed well water samples

Similar research was also conducted in the neighbour area of the Bjelovar-Bilogora County, which included analyses of water sampled at the milk collection centres during the period from 2011.-2016. Analysed water was 
used for human consumption, for the purposes of the households and as drinking water for cattle. The results have shown that out of the total of 147 examined water samples, 68 samples were microbiologically unsatisfactory, i.e. $46.3 \%$. The number of samples which did not correspond to the prescribed MPC values was 56 samples for intestine enterococci $(38.1 \%), 41$ samples to total coliforms $(27.9 \%), 32$ samples to E. coli (21.8\%). C. perfringens was determined in 11 samples $(7.5 \%)$, whereas $P$. aeruginosa was found in 3 samples $(2 \%)$. In the mentioned research, the number of unsatisfactory samples was decreasing during the years, which indicates the fact that more care was dedicated to well water quality control in milk collection centres (Denžić Lugomer et al. 2016). By further comparing the results obtained in this work to similar examinations conducted on the territory of the Republic of Croatia, it may be concluded that the number of unsatisfactory samples in previous years in various areas of Croatia was much higher (Smilović et al. 2011). Still, monitoring of drinking water from private wells is not conducted regularly, nor in the way the public water supply systems are being controlled. This may partly be explained by a relatively small number of samples analysed in some of the mentioned studies (Senta \& Marijanović Rajčić 2007). In some areas of Croatia connection to the public water supply system still isn't provided. Likewise, awareness of the Croatian citizens when it comes to health safety of the drinking water could be considered as insufficient. The water pollution most commonly occurs by the penetration of organic matter from septic tanks, improperly built or deteriorated sewage systems, cattle barns and farms with improper disposal of farmyard manure (Denžić Lugomer et al. 2016).

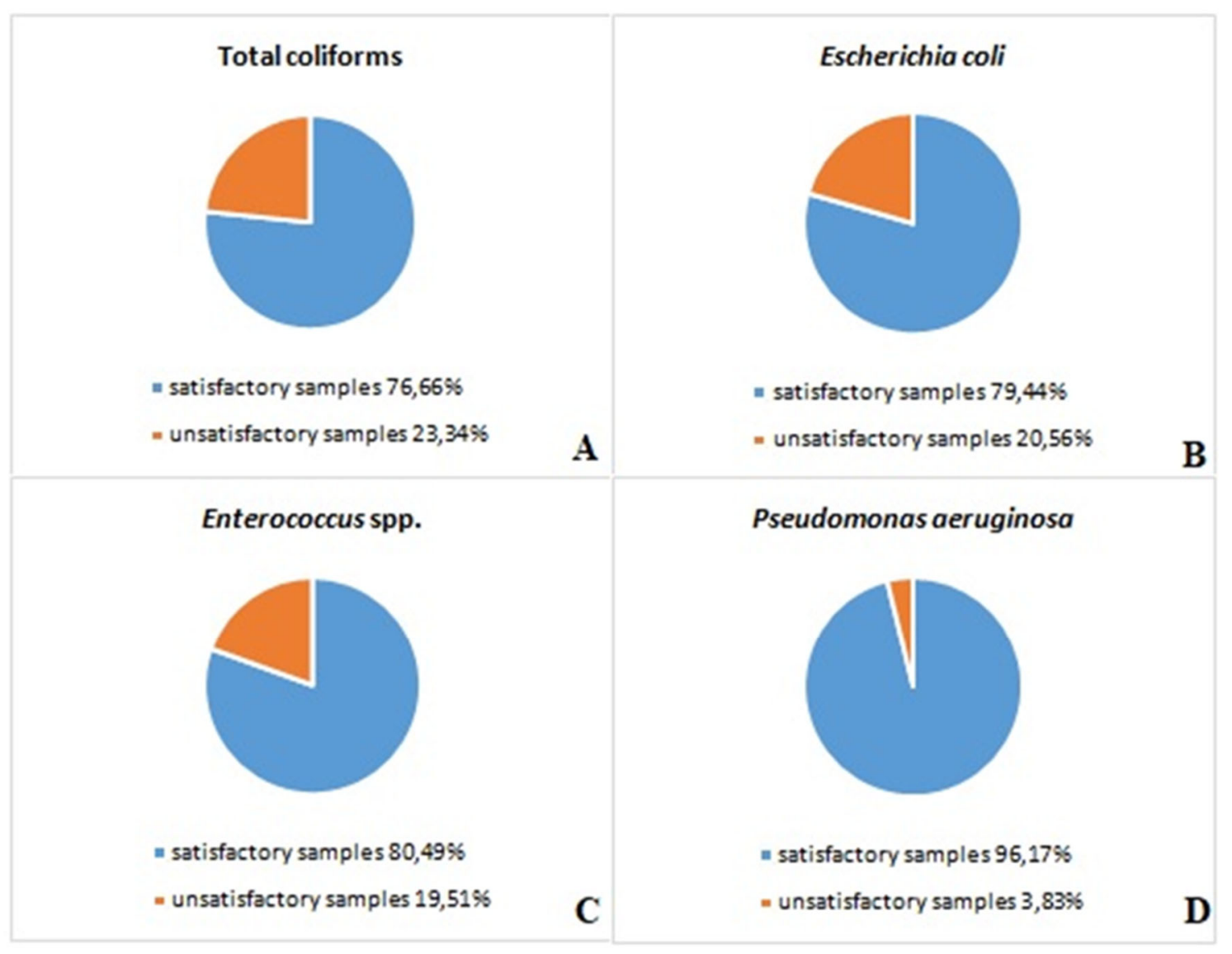

Figure 4. The proportion of satisfactory and unsatisfactory analysed water samples from private wells for the parameter of: A) total coliforms; B) Escherichia coli; C) Enterococcus spp.; D) Pseudomonas aeruginosa

The evaluation of drinking water health safety in the Međimurje County during the period 2004.- 2008., showed that $83.0 \%$ of water samples from individual water supply objects (wells or water pipes) were unsatisfactory in terms of health safety. The percentage of chemical and microbiological contamination in water samples was 45.5 $\%$ and $32.5 \%$ respectively. At the same time, $98.3 \%$ of drinking water samples from the public water supply system were confirmed as satisfactory (Smilović et al. 2011).

In the microbiological examination of the well water samples from the Zagreb surroundings, $61.8 \%$ of analysed well water samples had a poor microbiological quality. Out of the total of 34 examined water samples, 24 contained coliform bacteria and in two samples enterococci were determined (Senta \& Marijanović Rajčić 2007).

Due to the still high proportion of unsatisfactory samples, both from this study, but also from the previously mentioned studies, it may be concluded that, in addition to regular control of water performed by the institutions 
in charge of public health, it is necessary to particularly engage in the education of the Croatian citizens on the importance of drinking water safety, as well as on the proper procedures for wells disinfection.

\section{CONCLUSION}

The microbiological analysis of well water samples was conducted according to the standardised methods, pursuant to the current statutory regulations and existing water quality regulations in Croatia. This study showed that $24 \%$ of analysed samples were unsatisfactory according to the above-mentioned regulations. The most unsatisfactory samples pursuant to the Maximum Permissible Concentrations were total coliforms, E. coli and Enterococcus spp. Since in this study only samples of drinking water deriving from private wells were investigated, it is necessary to point out the need for continuous microbiological monitoring of well water, particularly in the places where it is used as the only source of drinking water for human and animal consumption. The quality of water from the private wells could vary, therefore it is important to determine the main sources of contamination and adequate measures to protect the wells from external pollution. The population of the Koprivnica-Križevci County, as well as the other consumers of drinking water deriving from private wells, needs to be educated on the importance of disinfection and should be provided with guidelines about appropriate disinfection procedures. Regular microbiological analysis before and after the disinfection would be very useful to establish the efficiency of the procedure.

\section{REFERENCES}

Cabral JPS (2010) Water Microbiology. Bacterial Pathogens and Water. International Journal of Environmental Research and Public Health, 7 10):3657-3703

Croatian Institute of Public Health (2018) Drinking water safety in Croatia (https://www.hzjz.hr/en/divisionof-environmental-health/drinking-water-safety-in-croatia)

Croatian water quality regulation (2017) Ordinance on conformity parameters, analytical methods, monitoring and drinking water safety plans, and keeping register of legal entities which provide public water supply. NN. $125 / 17$

Denžić Lugomer M, Jaki Tkalec V, Kiš M, Pavliček D, Furmeg S, Sokolović J (2017) Water quality on cattle farms in the northwest Croatia. Croatian Journal of Food Technology, Biotechnology and Nutrition 12(3-4):126130

Denžić Lugomer M, Jaki Tkalec V, Pavliček D, Kiš M, Sokolović J, Majnarić D (2016) Analiza pitke vode na sabiralištima mlijeka Bjelovarsko-bilogorske županije. Croatian Journal of Food Technology, Biotechnology and Nutrition 11(3-4):176-181

Denžić Lugomer M, Pavliček D, Kiš M, Jaki Tkalec V, Furmeg S, Sokolović S, Majnarić D (2019) Water quality on farms in northwest Croatia. Veterinarska stanica 50(2):115-124

EN ISO 14189:2016 - Water quality - Enumeration of Clostridium perfringens - Method using membrane filtration (ISO 14189:2013; EN ISO 14189:2016)

EN ISO 16266:2008 - Water quality - Detection and enumeration of Pseudomonas aeruginosa - Method by membrane filtration (ISO 16266:2006; EN ISO 16266:2008)

EN ISO 6222:2000 - Water quality - Enumeration of culturable micro-organisms - Colony count by inoculation in a nutrient agar culture medium (ISO 6222:1999; EN ISO 6222:1999)

EN ISO 7899-2:2000 - Water quality - Detection and enumeration of intestinal enterococci - Part 2: Membrane filtration method

EN ISO 9308 - 1:2014/A1:2017 - Water quality - Enumeration of Escherichia coli and coliform bacteria - Part 1: Membrane filtration method for waters with low bacterial background flora (ISO 9308-1:2014/Amd 1:2016; EN ISO 9308-1:2014/A1:2017)

Marjanović S, Tofant A (2008) Kvaliteta vode za napajanje goveda - čimbenik dobrobiti. Meso X:127-131

Official Gazette: Law on the Water Intended for Human Consumption. 56/13, 64/15, 104/17, 125/17, 115/18

Senta A, Marijanović Rajčić M (2007) Zdravstvena ispravnost pitke vode iz privatnih zdenaca u Zagrebu. Liječnički vjesnik 129:39-43

Smilović V, Vrbanec Megla L, Tarandek Strnad S (2011) Zdravstvena ispravnost vode za piće u javnim i individualnim vodoopskrbnim objektima u Međimurskoj županiji. Hrvatski časopis za javno zdravstvo 7(28): 1845-3082

Vukić Lušić D, Đandara A, Piškur V, Linšak Ž, Bilajac L, Lušić D (2017) Zdravstvena ispravnost vode za piće u Gorskom kotaru u petogodišnjem razdoblju od 2011. do 2015. Medicina Fluminensis 53:216-224

Vukić Lušić D, Herceg Z, Cenov A, Glad M, Lušić D (2017) Prisutnost P. aeruginosa u distribucijskim sustavima vode za piće u Primorsko-goranskoj županiji. Knjiga sažetaka 1. simpozij sanitarnog inžinjerstva s međunarodnim učešćem, Maestro, Daniel (ur.), Ljubljana: Inštitut za sanitarno inženirstvo, Ljubljana, Slovenia, $42-4$ 